\title{
SOFTSKILLS - KEPENTINGANNYA DALAM MEMENUHI KEBOLEHPASARAN PEKERJAAN TERHADAP GRADUAN POLITEKNIK JOHOR BAHRU (PJB)
}

\author{
Hamzah Bin Zakaria (UPLI) \\ Saidatul Nizan Bt. Nasroddin (JKE) \\ ZulHilmy Bin Hashim (UPLI) \\ Politeknik Johor Bahru
}

\begin{abstract}
Abstrak
Kejayaan pembangunan Softskills amat bergantung kepada mutu sistem pendidikan negara. Persaingan yang semakin meningkat di peringkat global memerlukan tenaga kerja yang cukup kompeten, beretika, kreatif serta mempunyai daya saing yang tinggi. Kemahiran Soft Skills dikalangan pelajar bukan lagi merupakan isu baru. Malah ia sudahpun menjadi isu global. Persaingan untuk mendapatkan pekerjaan telah menjadikan elemen Softskills semakin diperlukan. Setiap tahun, Politeknik Johor Bahru sentiasa terus menghasilkan graduan dan pelajar terlatih. Namun demikian didapati bilangan dan peratusan keluaran daripada Politeknik Johor Bahru ini masih tidak dapat menampung kekosongan pekerjaan meskipun keluaran sesuatu kumpulan pekerjaan itu, melebihi daripada kekosongan. Dalam era globalisasi dan perkembangan dunia sekarang, kebanyakan majikan memerlukan pekerja yang bukan hanya memiliki kemahiran teknikal atau hard skills sahaja tetapi juga mempunyai kemahiran Softskills. Pekerja yang mempunyai kemahiran tersebut akan dapat menyesuaikan diri dengan seтиa jenis pekerjaan dan bersifat serba boleh (multi skills) bersesuaian dengan keperluan dunia pekerja masa kini. Justeru,kertas kerja ini ditulis dengan tujuan untuk mengupas kepentingan elemen Softskills bagi melahirkan pelajar Politeknik Johor Bahru yang 'marketable' dan 'multi- tasking'. Silibus Latihan Industri telah digubal dengan memasukkan elemen softkills sebelum pelajar pergi menjalani latihan industri.Hasilnya penguasaan softskills dikalangan pelajar bertambah baik dari semasa ke semasa. Lantaran itu banyak peluang-peluang pekerjaan diberikan kepada pelajar PJB dan organisasi berpuashati terhadap prestasi yang ditunjukkan oleh pelajar
\end{abstract}

\section{PENDAHULUAN}

Kepentingan pembangunan sumber manusia dalam pembangunan sesebuah negara telah lama diakui. Beberapa buah negara mampu mencapai pertumbuhan ekonomi yang tinggi melalui pembangunan sumber manusia yang teliti walaupun mempunyai modal fizikal yang sangat sedikit. Sebaliknya terdapat beberapa buah negara yang kaya dengan modal fizikal, tetapi gagal mencapai pertumbuhan ekonomi yang tinggi kerana kelemahan pembangunan sumber manusia (Rahmah Ismail, 1999). Pembangunan manusia dapat memberikan sumbangan yang berkesan jika ia digunakan dengan betul dan berhemah. Apabila pekerja mula memegang jawatan dan tanggungjawab baru, mereka dilatih bagi mencapai matlamat penubuhan organisasi. Apabila persekitaraan, teknologi dan pemasaran berubah, pengetahuan dan kemahiran pekerja tersebut juga perlu berubah. Oleh itu pembangunan sumber manusia adalah berfungsi sebagai pembina aset yang menyelesaikan masalah secara kreatif untuk memastikan kejayaan tenaga pekerja terutama individu yang berkebolehan dan berminat dicapai (Kamal S. dan Mei, L. Y., 1996).

Tenaga manusia dalam era globalisasi bekerja dalam alam yang bersifat "flexitime" dan "self-paced" (Ibrahim Ahmad Barjunid, 2002). Dalam keadaan demikian, pekerja akan berdepan dengan perubahan yang tinggi dan berterusan seperti pertukaran personel, perubahan produk dan penstrukturan semula organisasi. Maka, sudah tentu akan berlaku peningkatan dalam permintaan oleh majikan terhadap pekerja yang bertanggungjawab, berupaya menangani cabaran pekerjaan, berkebolehan menyesuaikan diri mengikut keadaan dan sensitif kepada keadaan sekelilingnya. Oleh yang demikian, pekerja-pekerja dalam era globalisasi perlulah mempelajari nilai-nilai baru termasuk etika kerja, kepimpinan, kompetensi dalam teknologi maklumat, hubungan interpersonal dan sentiasa bersifat fleksibiliti dan analitik. 
Di antara cabaran utama yang perlu dihadapi dalam menjadikan Malaysia sebagai negara maju adalah untuk membentuk sebuah masyarakat yang makmur dengan ekonomi yang kukuh dan masyarakat yang progresif dan dapat manfaatkan teknologi bagi menyumbangkan kepada pembentukan peradaban sains dan teknologi pada masa depan. Salah satu unsur penting dalam menangani cabaran di atas adalah mengaktifkan keperluan sumber manusia dengan cara meningkat kebolehan dan kemahiran melalui pendidikan dan latihan yang tersusun serta komprehensif. Sehubungan dengan itu, untuk melatih, membentuk tenaga kerja yang diperlukan ke arah negara perindustrian, sumber manusia ini perlu mempunyai sikap kerja yang betul dan nilai-nilai positif seperti ikhlas, berdisiplin, menepati waktu, setia pada syarikat, tekun, dedikasi dan gigih bekerja, berkemahiran dalam komunikasi, mahir dalam informasi teknologi dan yang bersifat fleksibiliti (Kajian Separuh Penggal Rancangan Malaysia Ketujuh, 1999).

\section{STUDI LITERATUR}

\section{Kemahiran Softskills}

Sharifah Nor Puteh (2001), membuat takrifan kemahiran Softskills adalah kemahiran yang tidak khusus iaitu ia tidak mempunyai kurikulum yang khusus tetapi ianya boleh dipelajari melalui semua matapelajaran dengan kaedah intergrasi atau bersepadu. Kemahiran ini adalah bersifat fungsional dan adaptif untuk menjadikan seseorang pekerja itu cekap dan produktif.

National Skills Task Force (2000) pula mendefinasikan kemahiran Softskills sebagai kemahiran yang sama digunakan dalam pelbagai jenis pekerjaan merangkumi kemahiran komunikasi, kemahiran menyelesaikan masalah, kemahiran bekerja secara kumpulan, kemahiran teknologi maklumat, kemahiran matematik (application of number) dan kemahiran dalam membaiki perlakuan diri. Dalam kemahiran Softskills juga terdapat itemitem yang berkebolehan menjadualkan kerja, mendiagnostik masalah kerja, mengurus, merancang dan mengoperasi kerja secara teratur.
Kemahiran-kemahiran yang diperlukan oleh majikan seperti adaptabiliti, analitik, komunikasi, initiatif, interpersonal, kepemimpinan,keyakinan diri, dan berkerja dalam kumpulan merupakan kemahiran Softskills(Jim Espinoza,1999). Jessica Pumphery (2001), mentakrifkan kemahiran Softskills sebagai kemahiran yang boleh berubah-ubah (transferable), yang terdiri daripada gabungan-gabungan pelbagai kemahiran yang boleh meningkatkan produktiviti individu. Kemahiran Softskills ini juga bergantung kepada sektor ataupun kumpulan pekerjaan yang dilakukan oleh seseorang pekerja itu untuk melakukan proses kerja untuk mendapatkan hasil yang diharapkan iaitu, kemahiran komunikasi (communication), kemahiran feleksibiliti (flexibility), kemahiran teknologi informasi (technology information), pengurusan (management), kemahiran matematik (numeracy), pengoranisasian kerja (organisation of work), bekerja secara kumpulan (team working), penyelesian masalah ( problem sloving).

\section{Modul Latihan Industri}

Latihan industri merupakan komponen utama dalam kurikulum pembelajaran Politeknik Kementerian Pengajian Tinggi (KPTM). Semua pelajar disyaratkan lulus latihan industri sebelum diperakukan untuk penganugerahan Sijil atau Diploma Politeknik KPTM. Pelajar akan ditempatkan di organisasi tertentu selama satu semester bagi mendedahkan mereka kepada suasana pekerjaan sebenar. Mana kala matlamat latihan industri adalah untuk membolehkan pelajar mendapat kemahiran asas dan pengalaman dalam amalan professional selaras dengan hasrat politeknik untuk melahirkan ahli-ahli teknologi yang cekap dan bertanggung jawab kepada agama, bangsa dan negara.

Politeknik Johor Bahru menjalankan dua peringkat pengajian iaitu Sijil dan Diploma, dimana pelajar peringkat Sijil akan menjalankan latihan industri pada tahun ke 2 (semester 3). Manakala peringkat Diploma akan menjalankan latihan industri pada tahun ke 2 (semester 4). Program latihan industri didaftarkan dengan bilangan sebanyak 10 kredit, pelajar harus menamatkan latihan selama 5 bulan dengan peratusan kehadiran minimam 80 peratus. 
Diantara objektif program latihan industry ini adalah pertama, untuk mendedahkan pelajar-pelajar kepada amalan kejuruteraan dan kerja-kerja sebenar dalam bidang pengkhususan yang mereka ikuti.Keduanya, untuk didedahkan dengan cara-carareka bentuk yang sebenar, mengenal pasti masalah-masalah praktikal yang wujud dan cara-cara mengatasinya, dan ketiga, supaya dapat mempraktikkan dan menghubungkaitkan teori-teori yang telah dipelajari dengan daya kreativiti serta menyumbangkan buah fikiran yang bermutu kepada organisasi atau industri di tempat latihan.

Modul 'Soft skill Latihan Industri' telah mula amalkan di Politeknik bermula tahun 2008. Di dalam modul ini pelajar perlulah memenuhi lima kompetensi di mana kelima-lima kompetensi ini sama dengan objektif latihan Industri yang telah dikupas pada awal topik. Berdasarkan kompetensi yang disarankan, setiap kompetensi telah digariskan prestasi sasaran dan petunjuk prestasi agar perancangan dan dapatan dari pelajar dapat dipenuhi. Selain mendedahan terhadap modul 'softskill', pelajar juga harus didedahkan dengan taklimat mengenai prosedur yang perlu dilalui sebelum, semasa dan selepas latihan industry. Melalui taklimat ini pelajarakan didedahkan dengan maklumat dan prosedur yang jelas agar mereka mampu menjalani latihan pratikal sebagaimana yang diperlukan di dalam kurikulum institusi pengajian. Selain itu proses mendapatkan tempat latihan sehingga laporan latihan industry dapat dihasilkan dengan lancer dan sempurna.

Bahagian Pembangunan Kurikulum KPTM telah diberi tanggungjawab merealisasikan cadangan untuk mewujudkan kurikulum tersebut yang berasaskan kepada 5 kompentensi berikut iaitu:

i. Membina personaliti individu yang positif

ii. Kemahiran berkomunikasi

iii. Mengamalkan etika dan peraturan kerja yang baik

iv. Pendedahan kepada alam pekerjaan

v. Menghasilkan laporan harian latihan industri
Dalam kompetensi 1: Membina personaliti individu yang positif

a. Mempamerkan keyakinan diri dan berdikari

b. Mengamalkan disiplin diri yang baik

c. Mengamalkan sikap kerjasama dan kepimpinan

Dalam kompetensi 2 : Kemahiran berkomunikasi

a. Mengamalkan komunikasi dengan berkesan

b. Melibatkan diri dalam perbincangan dan tugas kumpulan

c. Melayan dan menghormati pelanggan

Dalam kompetensi 3 : Mengamalkan etika dan peraturan kerja yang baik

a. Melaksanakan arahan kerja dengan penuh tanggungjawab

b. Mengamalkan peraturan syarikat

c. Mengamalkan prosedur keselamatan yang baik

Dalam kompetensi 4 : Pendedahan kepada alam pekerjaan

a. Pendedahan kepada pengetahuan, kemahiran dan teknologi di tempat kerja.

Dalam kompetensi 5: Menghasilkan laporan harian latihan industri:

a. Menulis laporan harian

Pelaksanaan Modul Softskills ini adalah gabungan kaedah perbincangan dalam kumpulan, pengajaran, lakon peranan dan simulasi. Pelajar melalui proses pengalamian secara simulasi situasi latihan industri di dalam bilik kuliah. Jam pertemuan P\&P untuk modul ini adalah 1 jam. Ianya melibatkan pelajar semester 2 sijil dan 3 diploma. Tenaga pengajar modul ini adalah terdiri daripada semua Penyelaras Latihan Industri Jabatan (PLIJ) politeknik KPTM.

\section{Hubungan Modul Soft skill Latihan Industri Dengan Peningkatan Kemahiran Pelajar}

Terdapat perhubungan yang sangat rapat diantara soft skill latihan industri dengan peningkatan kemahiran pelajar, ini terbukti bahawa dengan latihan industri pelajar dapat menunjukkan kemajuan di dalam aspek pengetahuan, kemahiran, komunikasi 
dan ketahanan diri. Selain itu kemahiran yang diperolehi dapat dikongsi bersama dengan rakan-rakan pelajar yang lain.

\section{$<$ LampiranTabel 1>}

JADUAL 1 : Penilaian majikan terhadap pelajar yang menjalani latihan industri sesi Januari dan Julai 2008

Maklumat yang diperolehi dari Unit Perhubungan dan Latihan Industri Politeknik Johor Bahru (maklum balas organisasi terhadap pelajar bagi sesi latihan Januari dan Julai 2008) menyatakan bahawa kebanyakan organisasi telah memberi komen yang baik terhadap pelajar yang sedang menjalani latihan industri iaitu peratusan markah yang diberikan antara 75 $\%$ hingga $90 \%$ pada sesi Januari 2008. Manakala sesi Julai 2008 peratus markah yang diberikan antara 71 peratus hingga 84 peratus.

\section{Penyataan Masalah}

Persaingan untuk mendapatkan pekerjaan telah menjadi semakin sengit. Setiap tahun semakin banyak pusat pengajian tinggi dan pusat latihan tempatan menghasilkan graduan dan pelajar terlatih. Namun demikian didapati bilangan peratusan keluaran daripada institusi tersebut masih tidak dapat menampung kekosongan pekerjaan meskipun keluaran sesuatu kumpulan pekerjaan itu melebihi daripada kekosongan. Dalam era globalisasi dan perkembangan dunia sekarang, kebanyakan majikan memerlukan pekerja yang bukan hanya memiliki kemahiran teknikal tetapi juga kemahiran softskills.

\section{Objektif Kajian}

Objektif kajian ialah untuk mengkaji kemahiran softskills dalam memenuhi kebolehpasaran pekerjaan pada masa kini. Secara khususnya objektif kajian ialah untuk mengenalpasti perkara berikut :-

i. Meninjau dan membandingkan softskills amat berkesan bagi graduan PJB untuk mendapatkan pekerjaan samada di dalam bidang kejuruteraan atau bukan kejuruteraan ii. Mengenalpasti faktor berkaitan softskills yang ada pada graduan seperti kemahiran komunikasi interpersonal, kemahiran berfikir secara kritis dan kreatif, kemahiran menyelesaikan masalah, kemahiran analitikal / menganalisis, bekerja secara kumpulan /teamwork, penerapan dan pengalaman nilai-nilai murni.

iii. Pengetahuan kemahiran softskills dikalangan pelajar PJB.

iv. Pengetahuan kemahiran softksills secara khusus seperti modul Latihan Industri dikalangan pelajar PJB.

v. Pelajar yang tinggi CGPA lebih menguasai kemahiran softskills.

\section{SoalanKajian}

Soalan kajian telah dibentuk untuk mendapatkan maklumat yang diperlukan berhubung dengan kajian ini:

1. Apakah softskills amat berkesan bagi graduan PJB untuk mendapatkan pekerjaan samada di dalam bidang kejuruteraan atau bukan kejuruteraan.

2. Apakah perbezaan diantara pencapaian CGPA bagi graduan yang bekerja, tidak bekerja dan melanjutkan pelajaran.

3. Apakah hubungan diantara pencapaian CGPA dan kemahiran softskills bagi graduan bekerja, tidak bekerja dan melanjutkan pelajaran.

4. Apakah perbezaan di antara hubungan pencapaian CGPA, kemahiran softskills di peringkat sijil dan diploma bagi graduan bekerja, tidak bekerja dan melanjutkan pelajaran.

\section{SKOP KAJIAN}

Skop kajian ini melibatkan pelajar tahun akhir yang telah menamatkan pengajian di Politeknik Johor Bahru, yang terdiri daripada 4 buah Jabatan Utama. Kumpulan sasaran yang terlibat ialah semua graduan di semua peringkat pengajian dan mod pengajian.

\section{METHODOLOGY}

Kajian pengesanan graduan tahun 2008 telah menggunakan kajian secara on-line dengan bantuan dan kerjasama Jabatan Pengurusan Institut Pengajian Tinggi, KPTM. Semua graduan yang menghadiri 
majlis konvokesyen diminta untuk melayari laman web kajian pengesanan graduan iaitu http//:graduat.mohe.gov.my. Oleh yang demikian, bilangan responden adalah sama dengan bilangan graduan yang menghadiri majlis tersebut.

Populasi Kajian Pengesanan Graduan Tahun 2008 adalah semua graduan yang telah menamatkan pengajian dan mendapat Sijil atau Diploma masing-masing pada tahun 2007. Graduan telah dimaklumkan untuk mengisi Borang Kajian Pengesanan Graduan IPTA, IPTS dan Politeknik 2008 secara atas talian yang disediakan oleh Jabatan Pengurusan Institut Pengajian Tinggi (JPIPT) di antara 4 minggu sebelum dan 2 minggu selepas majlis konvokesyen. Maklumat yang diperolehi akan dikumpulkan dan dianalisis setelah sistem secara on-line ditutup. Data akan diperolehi daripada JPIPT dalam bentuk SPSS. Oleh yang demikian penganalisaan data akan dibuat menggunakan perisian tersebut.

Semua responden perlu melengkapkan soal selidik mengikut urutan bahagian. Sistem akan memberi peringatan sekiranya responden gagal melengkapkan mana-mana soalan dalam satu-satu bahagian sebelum ke bahagian seterusnya. Ini bertujuanuntukmengelakkanberlakukecicira n data. Borangsoal selidik merangkumi 7 bahagianutama, iaitu:

$\begin{array}{lrl}\text { Bahagian } & \text { A : } & \text { Latar Belakang Graduan } \\ \text { Bahagian } & \text { B }: & \text { Pengalaman Semasa } \\ & & \text { Mengikuti Pengajian Di } \\ & & \text { Institusi } \\ \text { Bahagian } & \text { C : } & \begin{array}{l}\text { Keberkesanan Sistem } \\ \text { Pengajian Dan Kesediaan }\end{array} \\ & & \text { Diri } \\ \text { Bahagian } & \text { D : } & \text { Melanjutkan Pengajian } \\ \text { Bahagian } & \text { E : Status Terkini } \\ \text { Bahagian } & \text { F: } & \text { Bekerja } \\ \text { Bahagian } & \text { G }: \begin{array}{l}\text { Belum/ Tidak Bekerja/ } \\ \text { Lain-Lain }\end{array}\end{array}$

\section{HASIL DAN PEMBAHASAN}

\section{Dapatan Kajian}

\section{<TerdapatpadaLampiran-Tabel 2>}

Jadual 2 : Jadual menunjukkan kemahiran Softskills terhadap pelajar kejuruteraan dan bukan kejuruteraan
Berdasarkan kepada jadual di atas menunjukkan bidang bukan kejuruteraan lebih menguasai kemahiran komunikasi interpersonal berbanding dengan graduan kejuruteraan. Sebanyak $77.9 \%$ bagi bidang bukan kejuruteraan yang mendapat keputusan memuaskan berbanding dengan kejuruteraan yang mendapat hanya $74.6 \%$.

Bidang kejuruteraan lebih menguasai kemahiran berfikir secara kritis dan kreatif berbanding dengan graduan bukan kejuruteraan. Sebanyak $82.4 \%$ bagi bidang bukan kejuruteraan yang mendapat keputusan memuaskan berbanding dengan kejuruteraan yang mendapat hanya $80.5 \%$.

Bidang kejuruteraan menguasai kemahiran menyelesaikan masaalah berbanding dengan graduan bukan kejuruteraan. Sebanyak 83\% bagi bidang bukan kejuruteraan yang mendapat keputusan memuaskan berbanding dengan kejuruteraan yang mendapat hanya $80.9 \%$.

Berdasarkan kepada jadual tersebut menunjukkan bidang kejuruteraan lebih menguasai kemahiran analitikal / menganalisis berbanding dengan graduan bukan kejuruteraan. Sebanyak $79.6 \%$ bagi bidang bukan kejuruteraan yang mendapat keputusan memuaskan berbanding dengan kejuruteraan yang mendapat hanya $75.5 \%$.

Graduan kejuruteraan lebih banyak menunjukkan penguasaan bekerja secara kumpulan /teamwork berbanding dengan graduan bukan kejuruteraan. Sebanyak 89.4\% bagi bidang bukan kejuruteraan yang mendapat keputusan memuaskan berbanding dengan kejuruteraan yang mendapat hanya $87.7 \%$.

Pencapaian CGPA graduan PJB bagi kategori bekerja, tidak bekerja dan melanjutkan pelajaran

〈Terdapat pada Lampiran - Tabel 3> Jadual 3 : Jadual menunjukkan pencapaian CGPA graduan PJB bagi kategori bekerja, tidak bekerja dan melanjutkan pelajaran

Berdasarkan kepada jadual 3 terlampir, menunjukkan pencapaian CGPA graduan PJB bagi kategori bekerja, tidak bekerja dan melanjutkan pelajaran. Bagi graduan 
yang bekerja, CGPA 3.5 hingga 4.00 sebanyak $9.4 \%$ sahaja. Bagi CGPA 3.00 hingga 3.49 sebanyak $50.3 \%$. Manakala 2.5 hingga 2.99 sebanyak $38.2 \%$ dan 2.1 $\%$ bagi graduan yang mendapat CGPA 2.00 hingga 2.49.Peratus bagi CGPA 3.5 hingga 4.00 sedikit dalam kategori bekerja berkemungkinan graduan lebih berminat untuk menyambung pelajaran di tempat yang lebih tinggi. Manakala CGPA 2.5 hingga 3.49 mempunyai peratus bekerja yang paling tinggi. Ini mungkin kerana syarikat hanya mengambil pelajar yang mempunyai CGPA yang tinggi sahaja untuk dipilih mengisi kekosongan tempat kerja di syarikat mereka. Manakala sebanyak $2.1 \%$ sahaja graduan yang mendapat CGPA kurang dari 2.49 yang mendapat peluang pekerjaan.

Bagi graduan yang melanjutkan pelajaran, CGPA 3.5 hingga 4.00 sebanyak $14.1 \%$ graduan yang berminat untuk melanjutkan pelajaran. Peratus ini lebih tinggi dari peratusan graduan yang bekerja bagi CGPA 3.5 hingga 4.00. Bagi CGPA 3.00 hingga 3.49 sebanyak $59.8 \%$. Manakala 2.5 hingga 2.99 sebanyak $25.5 \%$ dan 0.5 $\%$ sahaja bagi graduan yang mendapat CGPA 2.00 hingga 2.49. Peratus bagi CGPA 2.5 hingga 2.99 sedikit dalam kategori melanjutkan pelajaran berkemungkinan graduan tidak dapat peluang untuk menyambung pelajaran di tempat yang lebih tinggi. Manakala CGPA 2.5 hingga 4.00 mempunyai peratus melanjutkan pelajaran yang paling tinggi.

Bagi graduan yang belum bekerja, CGPA 3.5 hingga 4.00 sebanyak $6.6 \%$ sahaja. Bagi CGPA 3.00 hingga 3.49 sebanyak $50.6 \%$. Manakala 2.5 hingga 2.99 sebanyak $40.4 \%$ dan $2.5 \%$ bagi graduan yang mendapat CGPA 2.00 hingga 2.49.Peratus bagi CGPA 3.5 hingga 4.00 sedikit dalam kategori belum bekerja berkemungkinan graduan lebih berminat untuk menyambung pelajaran di tempat yang lebih tinggi. Manakala CGPA 2.5 hingga 3.49 mempunyai peratus bekerja yang paling tinggi. Ini mungkin kerana graduan lebih berminat untuk menambahkan lagi kemahiran di pusat latihan swasta bagi persiapan dari segi hardskill supaya mudah mendapat peluang pekerjaan..

\section{Hubungan CGPA dengan kemahiran softskills}

<Terdapat pada Lampiran - Tabel 4>

Jadual 4 : Jadual menunjukkan hubungan CGPA dengan kemahiran softskills

Berdasarkan kepada jadual 4 menunjukkan kemahiran komunikasi interpersonal terhadap graduan PJB berdasarkan CGPA yang berbeza bagi kategori bekerja, melanjutkan pelajaran dan tidak bekerja. Sampel hanya diambil bagi graduan yang mendapat CGPA 3.50 hingga 4.00 . Sebanyak $84 \%$ bersetuju memilih memuaskan bagi graduan yang bekerja mengatakan bahawa kemahiran komunikasi amat berguna di dalam pekerjaan . Bagi graduan yang melanjutkan pelajaran sebanyak $80.8 \%$ bersetuju memilih memuaskan bahawa komunikasi amat berguna di dalam pekerjaan. Manakala graduan yang belum bekerja hanya memilih $66.6 \%$ sahaja yang mengatakan bahawa kemahiran komunikasi amat berguna. Ini membuktikan bahawa dalam sektor pekerjaan, kemahiran komunikasi interpersonal amat berguna pada masa kini bagi membolehkan ia berjaya di dalam kerjayanya.

Kemahiran berfikir secara kritis dan kreatifterhadap graduan PJB berdasarkan CGPA yang berbeza bagi kategori bekerja, melanjutkan pelajaran dan tidak bekerja.. Sampel hanya diambil bagi graduan yang mendapat CGPA 3.50 hingga 4.00 . Sebanyak $82.1 \%$ bersetuju memilih memuaskan bagi graduan yang bekerja mengatakan bahawa kemahiran berfikir secara kritis dan kreatifamat berguna di dalam pekerjaan . Bagi graduan yang melanjutkan pelajaran sebanyak $92 \%$ bersetuju memilih memuaskan bahawa kemahiran komunikasi amat berguna di dalam pekerjaan. Manakala graduan yang belum bekerja memilih $88.6 \%$.

Berdasarkan kepada jadual tersebut menunjukkan kemahiran kemahiran menyelesaikan masalah terhadap graduan PJB berdasarkan CGPA yang berbeza bagi kategori bekerja, melanjutkan pelajaran dan tidak bekerja.. Sampel hanya diambil bagi graduan yang mendapat CGPA 3.50 hingga 4.00 . Sebanyak $84.2 \%$ bersetuju 
memilih memuaskan bagi graduan yang bekerja mengatakan bahawa kemahiran menyelesaikan masalah amat berguna di dalam pekerjaan . Bagi graduan yang melanjutkan pelajaran sebanyak $92.3 \%$ bersetuju memilih memuaskan bahawa kemahiran menyelesaikan masalah amat berguna. Manakala graduan yang belum bekerja memilih $85.7 \%$.

Berdasarkan kepada jadual di atas menunjukkan kemahiran analitikal / menganalisis terhadap graduan PJB berdasarkan CGPA yang berbeza bagi kategori bekerja, melanjutkan pelajaran dan tidak bekerja.. Sampel hanya diambil bagi graduan yang mendapat CGPA 3.50 hingga 4.00 . Sebanyak $82.2 \%$ bersetuju memilih memuaskan bagi graduan yang bekerja mengatakan bahawa kemahiran analitikal / menganalisis amat berguna di dalam pekerjaan . Bagi graduan yang melanjutkan pelajaran sebanyak $92.3 \%$ bersetuju memilih memuaskan bahawa kemahiran analitikal / menganalisis amat berguna di dalam pekerjaan. Manakala graduan yang belum bekerja memilih $77.2 \%$.

Berdasarkan kepada jadual di atas menunjukkan bekerja secara kumpulan / team work terhadap graduan PJB berdasarkan CGPA yang berbeza bagi kategori bekerja, melanjutkan pelajaran dan tidak bekerja.. Sampel hanya diambil bagi graduan yang mendapat CGPA 3.50 hingga 4.00 . Sebanyak $92.2 \%$ bersetuju memilih memuaskan bagi graduan yang bekerja mengatakan bahawa bekerja secara kumpulan / team work amat berguna di dalam pekerjaan. Bagi graduan yang melanjutkan pelajaran sebanyak $96.3 \%$ dan graduan yang belum bekerja memilih $82.9 \%$.

Ini bermakna bahawa kemahiran softskills seperti kemahiran komunikasi interpersonal, kemahiran berfikir secara kritis dan kreatif, kemahiran menyelesaikan masalah, kemahiran analitikal / menganalisis dan bekerja secara kumpulan / team work amat ditekankan di dalam kebolehpasaran pelajar PJB dalam menangani masalah kekurangan peluang pekerjaan.
Hubungan CGPA dengan kemahiran softskills berdasarkan peringkat diploma

<Lampiran pada Tabel 5>

Jadual 5 : Jadual menunjukan hubungan CGPA dengan kemahiran softskills berdasarkan peringkat diploma

Berdasarkan kepada jadual 5 menunjukkan kemahiran komunikasi interpersonal terhadap graduan PJB berdasarkan CGPA yang berbeza bagi kategori bekerja, melanjutkan pelajaran dan tidak bekerja.. Sampel hanya diambil bagi graduan yang mendapat CGPA 3.50 hingga 4.00 . Sebanyak $83.2 \%$ bersetuju memilih memuaskan bagi graduan yang bekerja mengatakan bahawa kemahiran komunikasi amat berguna di dalam pekerjaan . Bagi graduan yang melanjutkan pelajaran sebanyak $80.8 \%$ manakala graduan yang belum bekerja hanya memilih $66.6 \%$ sahaja.

Bagi kemahiran berfikir secara kritis dan kreatif pula, sampel hanya diambil bagi graduan yang mendapat CGPA 3.50 hingga 4.00 . Sebanyak $81.7 \%$ bersetuju memilih memuaskan bagi graduan yang bekerja mengatakan bahawa kemahiran berfikir secara kritis dan kreatif amat berguna di dalam pekerjaan . Bagi graduan yang melanjutkan pelajaran sebanyak $90.9 \%$ bersetuju memilih memuaskan manakala graduan yang belum bekerja hanya memilih $92.6 \%$ sahaja .

Sebanyak $81.7 \%$ bersetuju memilih memuaskan bagi graduan yang bekerja bahawa kemahiran menyelesaikan masalah amat berguna di dalam pekerjaan . Bagi graduan yang melanjutkan pelajaran sebanyak $100 \%$ bersetuju memilih memuaskan manakala graduan yang belum bekerja hanya memilih $75 \%$ sahaja yang mengatakan bahawa bahawa kemahiran menyelesaikan masalah amat berguna di dalam pekerjaan.

Sebanyak $82.9 \%$ bersetuju memilih memuaskan bagi graduan yang bekerja mengatakan bahawa kemahiran analitikal / menganalisis amat berguna di dalam pekerjaan . Bagi graduan yang melanjutkan pelajaran sebanyak $95.4 \%$ bersetuju memilih memuaskan manakala graduan 
yang belum bekerja hanya memilih $85.2 \%$ sahaja.

Berdasarkan kepada jadual di atas menunjukkan kemahiran bekerja secara kumpulan / team work berdasarkan peringkat diploma terhadap graduan PJB berdasarkan CGPA yang berbeza bagi kategori bekerja, melanjutkan pelajaran dan tidak bekerja.. Sampel hanya diambil bagi graduan yang mendapat CGPA 3.50 hingga 4.00 . Sebanyak $93.9 \%$ bersetuju memilih memuaskan bagi graduan yang bekerja mengatakan bahawa kemahiran bekerja secara kumpulan / team work amat berguna di dalam pekerjaan . Bagi graduan yang melanjutkan pelajaran sebanyak $95.4 \%$ bersetuju memilih memuaskan manakala graduan yang belum bekerja hanya memilih $85.2 \%$.

Sampel hanya diambil bagi graduan yang mendapat CGPA 3.50 hingga 4.00 . Sebanyak $92.6 \%$ bersetuju memilih memuaskan bagi graduan yang bekerja mengatakan bahawa kemahiran penerapan dan pengalaman nilai-nilai positif amat berguna di dalam pekerjaan . Bagi graduan yang melanjutkan pelajaran sebanyak 95.5 $\%$ bersetuju memilih memuaskan manakala graduan yang belum bekerja hanya memilih $92.6 \%$.

\section{Hubungan CGPA dengan kemahiran softskills berdasarkan peringkat sijil}

\section{<TerdapatpadaLampiran - Tabel 6> \\ Jadual 6: Jadual menunjukan hubungan CGPA dengan kemahiran softskills berdasarkan peringkat sijil}

Berdasarkan kepada jadual di atas menunjukkan kemahiran komunikasi interpersonal terhadap graduan PJB berdasarkan CGPA yang berbeza bagi kategori bekerja, melanjutkan pelajaran dan tidak bekerja.. Sampel hanya diambil bagi graduan yang mendapat CGPA 3.50 hingga 4.00 . Sebanyak $84.3 \%$ bersetuju memilih memuaskan bagi graduan yang bekerja mengatakan bahawa kemahiran komunikasi amat berguna di dalam pekerjaan . Bagi graduan yang melanjutkan pelajaran sebanyak $50 \%$ manakala graduan yang belum bekerja hanya memilih 50\% sahaja.

Bagi kemahiran berfikir secara kritis dan kreatif pula, sampel hanya diambil bagi graduan yang mendapat CGPA 3.50 hingga 4.00 . Sebanyak $84.2 \%$ bersetuju memilih memuaskan bagi graduan yang bekerja mengatakan bahawa kemahiran berfikir secara kritis dan kreatif amat berguna di dalam pekerjaan . Bagi graduan yang melanjutkan pelajaran sebanyak $100 \%$ bersetuju memilih memuaskan manakala graduan yang belum bekerja hanya memilih $75 \%$ sahaja .

Sebanyak $84.2 \%$ bersetuju memilih memuaskan bagi graduan yang bekerja bahawa kemahiran menyelesaikan masalah amat berguna di dalam pekerjaan . Bagi graduan yang melanjutkan pelajaran sebanyak $100 \%$ bersetuju memilih memuaskan manakala graduan yang belum bekerja hanya memilih $75 \%$ sahaja yang mengatakan bahawa bahawa kemahiran menyelesaikan masalah amat berguna di dalam pekerjaan.

Sebanyak $79 \%$ bersetuju memilih memuaskan bagi graduan yang bekerja mengatakan bahawa kemahiran analitikal / menganalisis amat berguna di dalam pekerjaan . Bagi graduan yang melanjutkan pelajaran sebanyak $75 \%$ bersetuju memilih memuaskan manakala graduan yang belum bekerja hanya memilih $50 \%$ sahaja.

Berdasarkan kepada jadual di atas menunjukkan kemahiran bekerja secara kumpulan / team work berdasarkan peringkat diploma terhadap graduan PJB berdasarkan CGPA yang berbeza bagi kategori bekerja, melanjutkan pelajaran dan tidak bekerja.. Sampel hanya diambil bagi graduan yang mendapat CGPA 3.50 hingga 4.00. Sebanyak $84.2 \%$ bersetuju memilih memuaskan bagi graduan yang bekerja mengatakan bahawa kemahiran bekerja secara kumpulan / team work amat berguna di dalam pekerjaan . Bagi graduan yang melanjutkan pelajaran sebanyak $100 \%$ bersetuju memilih 
memuaskan manakala graduan yang

belum bekerja hanya memilih $75 \%$.

Sampel hanya diambil bagi graduan yang mendapat CGPA 3.50 hingga 4.00 . Sebanyak $94.7 \%$ bersetuju memilih memuaskan bagi graduan yang bekerja mengatakan bahawa kemahiran penerapan dan pengalaman nilai-nilai positif amat berguna di dalam pekerjaan . Bagi graduan yang melanjutkan pelajaran sebanyak 100 $\%$ bersetuju memilih memuaskan manakala graduan yang belum bekerja hanya memilih $87.5 \%$.

\section{Cadangan}

Pelajar-pelajar bukan kejuruteraan hendaklah diberi tumpuan yang lebih di dalam kemahiran komunikasi interpersonal berbandung dengan pelajar kejuruteraan. Pelajar bukan kejuruteraan lebih potensi untuk bekerja di khalayak ramai untuk berkomunikasi dengan orang ramai. Bidang pekerjaan yang biasanya dipelopori oleh bukan kejuruteraan ialah hotel, sektor pelancongan, restoren makanan segera dan sebagainya.

Bidang kejuruteraan hendaklah lebih diberi penguasaan dalam kemahiran berfikir secara kritis dan kreatif berbanding dengan graduan bukan kejuruteraan. Ini berkemungkinan kerana graduan lebih banyak terlibat di dalam bidang teknikal yang banyak memerlukan kreativiti dan kritis dalam menyelesaikan masalah seperti sektor perkilangan.

Kemahiran analitik atau menganalisis juga hendaklah diberikan lebih penguasaan terhadap graduan kejuruteraan. Besar kemungkinan graduan kejuruteraan lebih banyak menganalisa sesuatu masalah di dalam sesuatu syarikat atau firma. Sebagai contoh ramai graduan kejuruteraan terlibat di dalam sector perkilangan. Rata-rata graduan menjadi juruteknik. Juruteknik biasanya akan menyelesaikan sesuatu masalah yang terdapat di dalam firma tersebut. Sebelum memperbaiki alatan tersebut, juruteknik terpaksa menganalisa terlebih dahulu peralatan tersebut. Setelah siap analisis barulah peralatan tersebut dibaiki.

Di dalam Modul Latihan Industri, pelajar didedahkan dengan lebih mendalam di dalam bidang kerja berpasukan atau team work. Pensyarah hendaklah lebih menekankan kepentingan kerja berpasukan di dalam kelas Softskills. Ini adalah kerana graduan banyak terlibat di dalam kerja berpasukan. Sebagai juruteknik hendaklah mengatur kerja-kerja dengan lebih teratur bagi memudahkan pekerja bawahan dapat melaksanakan tugasa yang diberkan dengan lebih sempurna.

Dalam mengisi kekosongan jawatan, pihak syarikat janganlah hanya memilih graduan yang tinggi CGPA sahaja berbanding dengan graduan yang sederhana pencapaiannya. Ini akan mengakibatkan lambakan graduan yang menganggur. Sesetengah graduan yang tinggi CGPA hanya bekelibihan di dalam peperiksaan sahaja berbanding dengan pelajar yang rendah dan sederhana. Mereka ini kadangkadang lebih berkemahiran hardskill berbanding dengan pelajar yang tinggi CGPAnya.

Bagi pelajar yang masih tidak mendapat kerja, dinasihatkan supaya graduan ini hendaklah menambahkan lagi ilmu kemahiran di pusat-pusat latihan swasta seperti Puspatri, ILP, IKM dan CIDB bagi membolehkan peluang pekerjaan mudah diperolehi sekiranyan mempunytai nilai tambahan.

Ini bermakna bahawa kemahiran softskills seperti kemahiran komunikasi interpersonal, kemahiran berfikir secara kritis dan kreatif, kemahiran menyelesaikan masalah, kemahiran analitikal / menganalisis dan bekerja secara kumpulan / team work amat ditekankan di dalam kebolehpasaran pelajar PJB dalam menangani masalah kekurangan peluang pekerjaan.

Majikan seringkali mencari dan menilai calon pekerja melalui beberapa kriteria kemahiran seperti kemahiran kepemimpinan, kemahiran bekerja secara kumpulan, kemahiran adaptibiliti, kemahiran interpersonal dan kemahiran komunikasi Daripada kemahiran-kemahiran 
di atas kemahiran komunikasi merupakan kemahiran yang seringkali di titikberatkan oleh majikan ketika mencari calon pekerja (Allen, 1998). Contohnya dalam kajian yang dilakukan oleh Indiana Commission for Higher Education pada 274 orang Pengurus Personel mengenai sepuluh (10) faktor apabila mengajikan pekerja dan didapati kemahiran komunikasi merupakan faktor yang pertama dalam menentukan calon pekerja ( Klopf \& Cambra, 1997). Kajian yang lain oleh Hultz, B.M. \& Others (1998), telah mengedarkan empat ratus dua puluh satu (421) majikan di seluruh Amerika. Hasil daripada kajian itu menunjukkan bahawa komunikasi lisan dan komunikasi tulisan mencatatkan punggutan yang tertinggi.

Graduan pada masa kini hendaklah sentiasa mempunyai kemahiran berfikir secara kritis dan kreatif . Pada hari ini permintaan untuk mendapatkan pekerja baru berkemahiran dalam satu-satu bidang tidak begitu penting tetapi untuk mendapat pekerja yang bersedia untuk dilatih dengan pelbagai kemahiran adalah yang lebih penting . Sementara itu kebanyakan syarikat menyediakan latihan untuk pekerjanya meningkatkan kemahiran yang berkaitan dengan proses, kaedah mengoperasikan sesuatu mesin bagi meningkatkan produk syarikat berkenaan. Bersedia untuk mengenalpasti masalah merupakan salah satu kemahiran Softskills yang penting dan keadaan ini merangkumi membuat keputusan, berfikiran kritis dan memahami persekitaran dunia pekerjaan yang diceburi .

Kebanyakan pekerjaan-pekerjaan baru di sekitar Pasir Gudang memerlukan kerja secara berkumpulan untuk mengatasi pekerjaan yang konvensional pada masa lalu. Bekerja dalam kumpulan boleh minimumkan kos dan dalam masa yang sama dapat meningkatkan produktiviti, menyumbangkan lebih banyak idea dan meningkatkan rasa tanggungjawab. Dalam kebanyakan industri seperti bidang kejuruteraan pembangunan dan pekerjaan berkumpulan (team - working) mendapat tempat yang tertinggi jika dibandingkan dengan bekerja secara sendirian.

Modul T3410 iaitu Modul Latihan Industri banyak membantu dalam perkembangan pelajar untuk memperolehi kemahiran
Softskills. Justeru itu, dicadangkan supaya modul ini ditambah jam pertemuan $\mathrm{P} \& \mathrm{P}$ dari 1 masa ke sekurang-kurangnya 3 masa. Ini akan menambahkan lagi jati diri, keyakinan diri dan ketahanan mental graduan sekiranya mereka keluar dari politeknik.

Dicadangkan supaya diperluaskan tenaga pengajar di kalangan semua pensyarah yang berminat untuk mengajar Modul Latihan Industri. Pada masa kini tenaga pengajar adalah terdiri dari Penyelaras Latihan Industri Jabatan (PLIJ) politeknik KPTM sahaja. Secara tidak langsung perkongsian ilmu dapat dilakukan dikalangan pensyarah.

\section{KESIMPULAN}

Kertas kerja ini mefokuskan betapa pentingnya kemahiran Softskills pada masa kini. Ini bermakna bahawa kemahiran softskills seperti kemahiran komunikasi interpersonal, kemahiran berfikir secara kritis dan kreatif, kemahiran menyelesaikan masalah, kemahiran analitikal / menganalisis dan bekerja secara kumpulan / team work amat ditekankan di dalam kebolehpasaran pelajar PJB dalam menangani masalah kekurangan peluang pekerjaan. Oleh itu, beberapa usaha perlu dilaksanakan bagi melahirkan lepasan graduan Politeknik Johor Bahru yang berdaya saing dan dapat memenuhi kehendak majikan masa kini. Antara usaha yang perlu dilaksanakan adalah penstrukturan kurikulum di semua peringkat pengajian bermula dari sekolah rendah hingga ke pengajian tinggi perlu lebih bersifat futuristik, fleksibel dan dinamik supaya pelajar yang dihasilkan berupaya menghadapi cabaran era globalisasi. Disamping itu penggunaan Modul Latihan Industri T 3410 di mana terdapat elemen Softskills di ajar sebelum pelajar menjalani latihan industri adalah perlu sebagaimana telah dilaksanakan di beberapa buah negara maju. Ini penting dengan dengan adanya modul ini para pelajar akan dapat dilatih secara terus mengikut modul yang ditetapkan. Apa yang diharapkan dengan terlaksananya dua saranan tersebut, para lepasan graduan Politeknik Johor Bahru akan lebih diterima oleh majikan dan sekaligus dapat menjana ke arah negara industri dengan lebih pantas. 


\section{RUJUKAN}

Kementerian Pengajian Tinggi Malaysia, (2008), Garis Panduan Latihan Industri Politeknik, Bahagian Pengurusan Politeknik

Kementerian Pengajian Tinggi Malaysia, (2006), Modul Latihan Industri, Bahagian Pembangunan Kurikulum, Jabatan Pengajian Politeknik dan Kolej Komuniti

Adli Azamin Shukri dan Muhammad Ali Shukri (2008). Neorosis Pekerjaan. DewanEkonomi (5) 2008. Kuala Lumpur :DBP

Ahmad Esa, Jailani Mohd Yunus dan Noraini Kaprawi (2005), Persepsi Pensyarah

Terhadap Penerapan Kemahiran Komunikasi Menerusi Ko Kurikulum di

Politeknik. Jurnal Penyelidikan Pendidikan, Jilid 7. Putrajaya : BahagianPerancangan dan Penyelidikan Dasar Pendidikan Kementerian PelajaranMalaysia.

Crosbie, Rowena. (2005). Learning the soft skills of leadership. Industrial andcommercial training, 37(1), 4551.http://en.wikipedia.org/wiki/Soft_s kills. capaian pada 12 jun 2008

Kementerian Pengajian Tinggi Malaysia. (2006). Modul pembangunan kemahiraninsaniah (SOFT SKILLS) untuk Institusi Pengajian Tinggi Malaysia. Serdang:

Universiti Putra Malaysia.

Ramzi, Nasser, \& Abouchedid Kamal. (2005). Graduates' perception of universitytraining in light of occupational attainment and university type: the case ofLebanon. Education and training, 47(2), 124-133.

Universiti Malaysia Perlis (2007), Penerapan dan Penilaian Kemahiran Insaniahwww.mohe.gov.my capaian pada 11 jun 2008 


\section{Lampiran}

Tabel 1

JADUAL 1 : PenilaianmajikanterhadappelajaryangmenjalanilatihanindustrisesiJanuaridanJulai 2008

\begin{tabular}{|l|l|l|l|l|}
\hline \multirow{2}{*}{ Bil } & Perkara & \multicolumn{3}{|l|}{ Kedudukan } \\
\cline { 3 - 5 } & & $\begin{array}{l}\text { Lemah } \\
(\boldsymbol{\%})\end{array}$ & $\begin{array}{l}\text { Sederhana } \\
(\%)\end{array}$ & $\begin{array}{l}\text { Baik } \\
(\%)\end{array}$ \\
\hline a & Keupayaanmenyesuaikandirikepadabudayakerjaorganisasi & 0 & $10(16)$ & $\begin{array}{l}90 \\
(84)\end{array}$ \\
\hline b & Keupayaanbekerjadengancepat & 0 & $20(21)$ & $\begin{array}{l}80 \\
(79)\end{array}$ \\
\hline c & Keupayaanbergaul & 0 & $15(16)$ & $\begin{array}{l}85 \\
(84)\end{array}$ \\
\hline d & Kemahiranberkomunikasi & 0 & $20(23)$ & $\begin{array}{l}80 \\
(77)\end{array}$ \\
\hline e & Disiplin & 0 & $15(29)$ & $\begin{array}{l}85 \\
(71)\end{array}$ \\
\hline f & Keseluruhan & 0 & $20(26)$ & $\begin{array}{l}80 \\
(74)\end{array}$ \\
\hline
\end{tabular}

Nota : nilaididalam ( ) adalahperatusuntuksesiJulai 2008

Tabel 2

Jadual 2 : Jadual menunjukkan kemahiran Softskills terhadap pelajar kejuruteraan dan bukan kejuruteraan

\begin{tabular}{|c|c|c|c|c|c|c|}
\hline $\begin{array}{l}\text { Kemahiran } \\
\text { Softskills }\end{array}$ & Bidang & $\begin{array}{l}\text { Amat } \\
\text { Tidak } \\
\text { Memuaska } \\
\mathrm{n}\end{array}$ & $\begin{array}{l}\text { Tidak } \\
\text { Memuaska } \\
\mathrm{n}\end{array}$ & $\begin{array}{l}\text { Sederhan } \\
\text { a }\end{array}$ & $\begin{array}{l}\text { Memuaska } \\
\mathrm{n}\end{array}$ & $\begin{array}{l}\text { Amat } \\
\text { Memuaska } \\
\mathrm{n}\end{array}$ \\
\hline \multirow{2}{*}{$\begin{array}{l}\text { Kemahiran } \\
\text { komunikasi } \\
\text { interpersonal }\end{array}$} & $\begin{array}{l}\text { Kejuruteraa } \\
\mathrm{n}\end{array}$ & $28.6 \%$ & $36.4 \%$ & $25.6 \%$ & $22.9 \%$ & $19.3 \%$ \\
\hline & $\begin{array}{l}\text { Bukan } \\
\text { Kejuruteraa } \\
n\end{array}$ & $42.9 \%$ & $30.3 \%$ & $25.3 \%$ & $19.0 \%$ & $18.4 \%$ \\
\hline \multirow{2}{*}{$\begin{array}{l}\text { Kemahiran } \\
\text { berfikir } \\
\text { secara kritis } \\
\text { dan kreatif }\end{array}$} & $\begin{array}{l}\text { Kejuruteraa } \\
n\end{array}$ & $14.3 \%$ & $29.4 \%$ & $24.8 \%$ & $22.0 \%$ & $23.5 \%$ \\
\hline & $\begin{array}{l}\text { Bukan } \\
\text { Kejuruteraa } \\
\text { n }\end{array}$ & $85.7 \%$ & $52.9 \%$ & $48.9 \%$ & $46.1 \%$ & $47.4 \%$ \\
\hline \multirow[t]{2}{*}{$\begin{array}{l}\text { Kemahiran } \\
\text { menyelesaika } \\
\text { n masalah }\end{array}$} & $\begin{array}{l}\text { Kejuruteraa } \\
\mathrm{n}\end{array}$ & $33.3 \%$ & $28.6 \%$ & $22.0 \%$ & $22.2 \%$ & $24.6 \%$ \\
\hline & $\begin{array}{l}\text { Bukan } \\
\text { Kejuruteraa } \\
\text { n }\end{array}$ & $66.7 \%$ & $52.4 \%$ & $50.0 \%$ & $46.7 \%$ & $45.3 \%$ \\
\hline \multirow[t]{2}{*}{$\begin{array}{l}\text { Kemahiran } \\
\text { analitikal / } \\
\text { menganalisis }\end{array}$} & $\begin{array}{l}\text { Kejuruteraa } \\
n\end{array}$ & $28.6 \%$ & $37.5 \%$ & $49.3 \%$ & $52.8 \%$ & $57.9 \%$ \\
\hline & $\begin{array}{l}\text { Bukan } \\
\text { Kejuruteraa }\end{array}$ & $71.4 \%$ & $62.5 \%$ & $50.7 \%$ & $47.2 \%$ & $42.1 \%$ \\
\hline
\end{tabular}


SOFTSKILLS - KEPENTINGANNYA DALAM MEMENUHI KEBOLEHPASARAN

PEKERJAAN TERHADAP GRADUAN POLITEKNIK JOHOR BAHRU (PJB)

\begin{tabular}{|c|c|c|c|c|c|c|}
\hline $\begin{array}{l}\text { Kemahiran } \\
\text { Softskills }\end{array}$ & Bidang & $\begin{array}{l}\text { Amat } \\
\text { Tidak } \\
\text { Memuaska } \\
\text { n }\end{array}$ & $\begin{array}{l}\text { Tidak } \\
\text { Memuaska } \\
\text { n }\end{array}$ & $\begin{array}{l}\text { Sederhan } \\
\text { a }\end{array}$ & $\begin{array}{l}\text { Memuaska } \\
\mathrm{n}\end{array}$ & $\begin{array}{l}\text { Amat } \\
\text { Memuaska } \\
\mathrm{n}\end{array}$ \\
\hline & $\mathrm{n}$ & & & & & \\
\hline \multirow{2}{*}{$\begin{array}{l}\text { Bekerja } \\
\text { secara } \\
\text { kumpulan } \\
\text { team work }\end{array}$} & $\begin{array}{l}\text { Kejuruteraa } \\
n\end{array}$ & $54.5 \%$ & $30.0 \%$ & $50.9 \%$ & $52.2 \%$ & $54.7 \%$ \\
\hline & $\begin{array}{l}\text { Bukan } \\
\text { Kejuruteraa } \\
\mathrm{n}\end{array}$ & $45.5 \%$ & $70.0 \%$ & $49.1 \%$ & $47.8 \%$ & $45.3 \%$ \\
\hline \multirow{2}{*}{$\begin{array}{l}\text { Penerapan } \\
\text { dan } \\
\text { pengalaman } \\
\text { nilai-nilai } \\
\text { positif }\end{array}$} & $\begin{array}{l}\text { Kejuruteraa } \\
n\end{array}$ & $44.4 \%$ & $36.8 \%$ & $51.1 \%$ & $53.5 \%$ & $53.2 \%$ \\
\hline & $\begin{array}{l}\text { Bukan } \\
\text { Kejuruteraa } \\
\mathrm{n}\end{array}$ & $55.6 \%$ & $63.2 \%$ & $48.9 \%$ & $46.5 \%$ & $46.8 \%$ \\
\hline
\end{tabular}


Table 3

Jadual 3: Jadual menunjukkan pencapaian CGPA graduan PJB bagi kategori bekerja, tidak bekerja dan melanjutkan pelajaran

\begin{tabular}{|ll|l|l|}
\hline Pecahan & Frequency & Percent \\
\hline Bekerja & $.50-4.00$ & 101 & 9.4 \\
& $.00-3.49$ & 539 & 50.3 \\
& $.50-2.99$ & 409 & 38.2 \\
& $.00-2.49$ & 22 & 2.1 \\
& & & \\
\hline Melanjutkan Pengajian & $.50-4.00$ & 26 & 14.1 \\
& $.00-3.49$ & 110 & 59.8 \\
& $.50-2.99$ & 47 & 25.5 \\
& $.00-2.49$ & 1 & .5 \\
& & & \\
\hline Belum Bekerja & $.50-4.00$ & 35 & 6.6 \\
& $.00-3.49$ & 268 & 50.6 \\
$.50-2.99$ & 214 & 40.4 \\
$.00-2.49$ & 13 & 2.5 \\
& & \\
& &
\end{tabular}

Tabel 4

Jadual 4 : Jadual menunjukkan hubungan CGPA dengan kemahiran softskills

\begin{tabular}{|c|c|c|c|c|c|c|c|}
\hline $\begin{array}{l}\text { KEMAHIR } \\
\text { AN } \\
\text { SOFTSKIL } \\
\text { LS } \\
\end{array}$ & $\begin{array}{l}\text { CGP } \\
\text { A } \\
\end{array}$ & $\begin{array}{l}\text { PECAH } \\
\text { AN }\end{array}$ & $\begin{array}{l}\text { Amat } \\
\text { Tidak } \\
\text { Memuas } \\
\text { kan } \\
\end{array}$ & $\begin{array}{l}\text { Tidak } \\
\text { Memuas } \\
\text { kan }\end{array}$ & $\begin{array}{l}\text { Sederh } \\
\text { ana }\end{array}$ & $\begin{array}{l}\text { Memuas } \\
\text { kan }\end{array}$ & $\begin{array}{l}\text { Amat } \\
\text { Memuas } \\
\text { kan }\end{array}$ \\
\hline \multirow{3}{*}{$\begin{array}{l}\text { Kemahiran } \\
\text { komunikasi } \\
\text { interperson } \\
\text { al }\end{array}$} & \multirow{3}{*}{$\begin{array}{l}3.5- \\
4.00\end{array}$} & Bekerja & $2.0 \%$ & $0.0 \%$ & $15.0 \%$ & $60.0 \%$ & $24.0 \%$ \\
\hline & & $\begin{array}{l}\text { Melanjut } \\
\text { kan } \\
\text { Pengajia } \\
n\end{array}$ & $0.0 \%$ & $0.0 \%$ & $19.2 \%$ & $38.5 \%$ & $42.3 \%$ \\
\hline & & $\begin{array}{l}\text { Belum } \\
\text { Bekerja }\end{array}$ & $2.9 \%$ & $2.9 \%$ & $25.7 \%$ & $54.3 \%$ & $14.3 \%$ \\
\hline \multirow{3}{*}{$\begin{array}{l}\text { Kemahiran } \\
\text { menyelesai } \\
\text { kan } \\
\text { masalah }\end{array}$} & \multirow{3}{*}{$\begin{array}{l}3.5- \\
4.00\end{array}$} & Bekerja & $1.00 \%$ & $0.00 \%$ & $14.90 \%$ & $62.40 \%$ & $21.80 \%$ \\
\hline & & $\begin{array}{l}\text { Melanjut } \\
\text { kan } \\
\text { Pengajia } \\
\mathrm{n}\end{array}$ & $0.0 \%$ & $3.80 \%$ & $3.80 \%$ & $57.70 \%$ & $34.60 \%$ \\
\hline & & $\begin{array}{l}\text { Belum } \\
\text { Bekerja }\end{array}$ & $0.00 \%$ & $2.90 \%$ & $11.40 \%$ & $60.00 \%$ & $25.70 \%$ \\
\hline \multirow{3}{*}{$\begin{array}{l}\text { Kemahiran } \\
\text { analitikal / } \\
\text { menganalis } \\
\text { is }\end{array}$} & \multirow{3}{*}{$\begin{array}{l}3.5- \\
4.00\end{array}$} & Bekerja & $1.00 \%$ & $0.00 \%$ & $16.80 \%$ & $63.40 \%$ & $18.80 \%$ \\
\hline & & $\begin{array}{l}\text { Melanjut } \\
\text { kan } \\
\text { Pengajia } \\
\mathrm{n}\end{array}$ & $0.00 \%$ & $0.00 \%$ & $7.70 \%$ & $57.70 \%$ & $34.60 \%$ \\
\hline & & $\begin{array}{l}\text { Belum } \\
\text { Bekerja }\end{array}$ & $2.90 \%$ & $0.00 \%$ & $20.00 \%$ & $54.30 \%$ & $22.90 \%$ \\
\hline Bekerja & & Bekerja & $1.00 \%$ & $0.00 \%$ & $6.90 \%$ & $49.50 \%$ & $42.60 \%$ \\
\hline
\end{tabular}




\begin{tabular}{|c|c|c|c|c|c|c|c|}
\hline \multirow[t]{2}{*}{$\begin{array}{l}\text { secara } \\
\text { kumpulan } \\
/ \\
\text { team work }\end{array}$} & \multirow[t]{2}{*}{$\begin{array}{l}3.5- \\
4.00\end{array}$} & $\begin{array}{l}\text { Melanjut } \\
\text { kan } \\
\text { Pengajia } \\
\mathrm{n}\end{array}$ & $0.00 \%$ & $0.00 \%$ & $3.80 \%$ & $42.30 \%$ & $53.80 \%$ \\
\hline & & $\begin{array}{l}\text { Belum } \\
\text { Bekerja }\end{array}$ & $0.00 \%$ & $2.90 \%$ & $14.30 \%$ & $54.30 \%$ & $28.60 \%$ \\
\hline
\end{tabular}

Tabel 5

Jadual 5: Jadual menunjukan hubungan CGPA dengan kemahiran softskills berdasarkan peringkat diploma

\begin{tabular}{|c|c|c|c|c|c|c|c|}
\hline $\begin{array}{l}\text { KEMAHIRAN } \\
\text { SOFTSKILLS }\end{array}$ & CGPA & $\begin{array}{l}\text { PECAH } \\
\text { AN }\end{array}$ & $\begin{array}{l}\text { Amat } \\
\text { Tidak } \\
\text { Memuas } \\
\text { kan }\end{array}$ & $\begin{array}{l}\text { Tidak } \\
\text { Memuas } \\
\text { kan }\end{array}$ & $\begin{array}{l}\text { Sederh } \\
\text { ana }\end{array}$ & $\begin{array}{l}\text { Memuas } \\
\text { kan }\end{array}$ & $\begin{array}{l}\text { Amat } \\
\text { Memuas } \\
\text { kan }\end{array}$ \\
\hline \multirow{3}{*}{$\begin{array}{l}\text { Kemahiran } \\
\text { komunikasi } \\
\text { interpersonal }\end{array}$} & \multirow{3}{*}{$3.5-4.00$} & Bekerja & $2.40 \%$ & $0.00 \%$ & $\begin{array}{l}14.60 \\
\%\end{array}$ & $58.50 \%$ & $24.40 \%$ \\
\hline & & $\begin{array}{l}\text { Melanjut } \\
\text { kan } \\
\text { Pengajia } \\
\text { n }\end{array}$ & $0.00 \%$ & $0.00 \%$ & $\begin{array}{l}13.60 \\
\%\end{array}$ & $45.50 \%$ & $40.90 \%$ \\
\hline & & $\begin{array}{l}\text { Belum } \\
\text { Bekerja }\end{array}$ & $0.00 \%$ & $3.70 \%$ & $\begin{array}{l}22.20 \\
\%\end{array}$ & $59.30 \%$ & $14.80 \%$ \\
\hline \multirow{3}{*}{$\begin{array}{l}\text { Kemahiran } \\
\text { berfikir secara } \\
\text { kritis dan kreatif }\end{array}$} & \multirow{3}{*}{$3.5-4.00$} & Bekerja & $1.20 \%$ & $0.00 \%$ & $\begin{array}{l}17.10 \\
\%\end{array}$ & $56.10 \%$ & $25.60 \%$ \\
\hline & & $\begin{array}{l}\text { Melanjut } \\
\text { kan } \\
\text { Pengajia } \\
\mathrm{n}\end{array}$ & $0.00 \%$ & $4.50 \%$ & $4.50 \%$ & $54.50 \%$ & $36.40 \%$ \\
\hline & & $\begin{array}{l}\text { Belum } \\
\text { Bekerja }\end{array}$ & $0.00 \%$ & $0.00 \%$ & $7.40 \%$ & $70.40 \%$ & $22.20 \%$ \\
\hline \multirow{3}{*}{$\begin{array}{l}\text { Kemahiran } \\
\text { menyelesaikan } \\
\text { masalah }\end{array}$} & \multirow{3}{*}{$3.5-4.00$} & Bekerja & $1.20 \%$ & $0.00 \%$ & $\begin{array}{l}14.60 \\
\%\end{array}$ & $63.40 \%$ & $20.70 \%$ \\
\hline & & $\begin{array}{l}\text { Melanjut } \\
\text { kan } \\
\text { Pengajia } \\
\text { n } \\
\end{array}$ & $0.00 \%$ & $4.50 \%$ & $4.50 \%$ & $50.00 \%$ & $40.90 \%$ \\
\hline & & $\begin{array}{l}\text { Belum } \\
\text { Bekerja }\end{array}$ & $0.00 \%$ & $0.00 \%$ & $\begin{array}{l}11.10 \\
\%\end{array}$ & $63.00 \%$ & $25.90 \%$ \\
\hline \multirow{3}{*}{$\begin{array}{l}\text { Kemahiran } \\
\text { analitikal } \\
\quad \text { / menganalisis }\end{array}$} & \multirow{3}{*}{$3.5-4.00$} & Bekerja & $1.20 \%$ & $0.00 \%$ & $\begin{array}{l}15.90 \\
\%\end{array}$ & $64.60 \%$ & $18.30 \%$ \\
\hline & & $\begin{array}{l}\text { Melanjut } \\
\text { kan } \\
\text { Pengajia } \\
\text { n } \\
\end{array}$ & $0.00 \%$ & $0.00 \%$ & $4.50 \%$ & $63.60 \%$ & $31.80 \%$ \\
\hline & & $\begin{array}{l}\text { Belum } \\
\text { Bekerja }\end{array}$ & $0.00 \%$ & $0.00 \%$ & $\begin{array}{l}14.80 \\
\%\end{array}$ & $59.30 \%$ & $25.90 \%$ \\
\hline \multirow{3}{*}{$\begin{array}{l}\text { Bekerja secara } \\
\text { kumpulan / team } \\
\text { work }\end{array}$} & \multirow{3}{*}{$3.5-4.00$} & Bekerja & $1.20 \%$ & $0.00 \%$ & $4.90 \%$ & $52.40 \%$ & $41.50 \%$ \\
\hline & & $\begin{array}{l}\text { Melanjut } \\
\text { kan } \\
\text { Pengajia } \\
\mathrm{n}\end{array}$ & $0.00 \%$ & $0.00 \%$ & $4.50 \%$ & $40.90 \%$ & $54.50 \%$ \\
\hline & & $\begin{array}{l}\text { Belum } \\
\text { Bekerja }\end{array}$ & $0.00 \%$ & $0.00 \%$ & $\begin{array}{l}14.80 \\
\%\end{array}$ & $55.60 \%$ & $29.60 \%$ \\
\hline
\end{tabular}




\begin{tabular}{|c|c|c|c|c|c|c|c|}
\hline $\begin{array}{l}\text { KEMAHIRAN } \\
\text { SOFTSKILLS }\end{array}$ & CGPA & $\begin{array}{l}\text { PECAH } \\
\text { AN }\end{array}$ & $\begin{array}{l}\text { Amat } \\
\text { Tidak } \\
\text { Memuas } \\
\text { kan }\end{array}$ & $\begin{array}{l}\text { Tidak } \\
\text { Memuas } \\
\text { kan }\end{array}$ & $\begin{array}{l}\text { Sederh } \\
\text { ana }\end{array}$ & $\begin{array}{l}\text { Memuas } \\
\text { kan }\end{array}$ & $\begin{array}{l}\text { Amat } \\
\text { Memuas } \\
\text { kan }\end{array}$ \\
\hline \multirow{3}{*}{$\begin{array}{l}\text { Penerapan dan } \\
\text { pengalaman } \\
\text { nilai-nilai positif }\end{array}$} & \multirow{3}{*}{$3.5-4.00$} & Bekerja & $1.20 \%$ & $0.00 \%$ & $6.10 \%$ & $52.40 \%$ & $40.20 \%$ \\
\hline & & $\begin{array}{l}\text { Melanjut } \\
\text { kan } \\
\text { Pengajia } \\
\text { n }\end{array}$ & $0.00 \%$ & $0.00 \%$ & $4.50 \%$ & $45.50 \%$ & $50.00 \%$ \\
\hline & & $\begin{array}{l}\text { Belum } \\
\text { Bekerja }\end{array}$ & $0.00 \%$ & $0.00 \%$ & $7.40 \%$ & $51.90 \%$ & $40.70 \%$ \\
\hline
\end{tabular}

Tabel 6

Jadual 6: Jadual menunjukan hubungan CGPA dengan kemahiran softskills berdasarkan peringkat sijil

\begin{tabular}{|c|c|c|c|c|c|c|c|}
\hline $\begin{array}{l}\text { KEMAHIRAN } \\
\text { SOFTSKILLS }\end{array}$ & CGPA & $\begin{array}{l}\text { PECAH } \\
\text { AN }\end{array}$ & $\begin{array}{l}\text { Amat } \\
\text { Tidak } \\
\text { Memuas } \\
\text { kan } \\
\end{array}$ & $\begin{array}{l}\text { Tidak } \\
\text { Memuas } \\
\text { kan }\end{array}$ & $\begin{array}{l}\text { Sederh } \\
\text { ana }\end{array}$ & $\begin{array}{l}\text { Memuas } \\
\text { kan }\end{array}$ & $\begin{array}{l}\text { Amat } \\
\text { Memua } \\
\text { skan } \\
\end{array}$ \\
\hline \multirow{3}{*}{$\begin{array}{l}\text { Kemahiran } \\
\text { komunikasi } \\
\text { interpersonal }\end{array}$} & \multirow{3}{*}{$3.5-4.00$} & Bekerja & $0.00 \%$ & $0.00 \%$ & $\begin{array}{l}15.80 \\
\% \\
\end{array}$ & $63.20 \%$ & $21.10 \%$ \\
\hline & & $\begin{array}{l}\text { Melanjut } \\
\text { kan } \\
\text { Pengajia } \\
\mathrm{n}\end{array}$ & $0.00 \%$ & $0.00 \%$ & $\begin{array}{l}50.00 \\
\%\end{array}$ & $0.00 \%$ & $50.00 \%$ \\
\hline & & $\begin{array}{l}\text { Belum } \\
\text { Bekerja }\end{array}$ & $12.50 \%$ & $0.00 \%$ & $\begin{array}{l}37.50 \\
\%\end{array}$ & $37.50 \%$ & $12.50 \%$ \\
\hline \multirow{3}{*}{$\begin{array}{l}\text { Kemahiran } \\
\text { berfikir secara } \\
\text { kritis dan kreatif }\end{array}$} & \multirow{3}{*}{$3.5-4.00$} & Bekerja & $0.00 \%$ & $0.00 \%$ & $\begin{array}{l}15.80 \\
\%\end{array}$ & $52.60 \%$ & $31.60 \%$ \\
\hline & & $\begin{array}{l}\text { Melanjut } \\
\text { kan } \\
\text { Pengajia } \\
\mathrm{n} \\
\end{array}$ & $0.00 \%$ & $0.00 \%$ & $0.00 \%$ & $\begin{array}{l}100.00 \\
\%\end{array}$ & $0.00 \%$ \\
\hline & & $\begin{array}{l}\text { Belum } \\
\text { Bekerja }\end{array}$ & $12.50 \%$ & $0.00 \%$ & $\begin{array}{l}12.50 \\
\%\end{array}$ & $50.00 \%$ & $25.00 \%$ \\
\hline \multirow{3}{*}{$\begin{array}{l}\text { Kemahiran } \\
\text { menyelesaikan } \\
\text { masalah }\end{array}$} & \multirow{3}{*}{$3.5-4.00$} & Bekerja & $0.00 \%$ & $0.00 \%$ & $\begin{array}{l}15.80 \\
\%\end{array}$ & $57.90 \%$ & $26.30 \%$ \\
\hline & & $\begin{array}{l}\text { Melanjut } \\
\text { kan } \\
\text { Pengajia } \\
\text { n } \\
\end{array}$ & $0.00 \%$ & $0.00 \%$ & $0.00 \%$ & $\begin{array}{l}100.00 \\
\%\end{array}$ & $0.00 \%$ \\
\hline & & $\begin{array}{l}\text { Belum } \\
\text { Bekerja }\end{array}$ & $0.00 \%$ & $12.50 \%$ & $\begin{array}{l}12.50 \\
\%\end{array}$ & $50.00 \%$ & $25.00 \%$ \\
\hline \multirow{3}{*}{$\begin{array}{l}\text { Kemahiran } \\
\text { analitikal } \\
\text { / menganalisis }\end{array}$} & \multirow{3}{*}{$3.5-4.00$} & Bekerja & $0.00 \%$ & $0.00 \%$ & $\begin{array}{l}21.10 \\
\%\end{array}$ & $57.90 \%$ & $21.10 \%$ \\
\hline & & $\begin{array}{l}\text { Melanjut } \\
\text { kan } \\
\text { Pengajia } \\
\mathrm{n} \\
\end{array}$ & $0.00 \%$ & $0.00 \%$ & $\begin{array}{l}25.00 \\
\%\end{array}$ & $25.00 \%$ & $50.00 \%$ \\
\hline & & $\begin{array}{l}\text { Belum } \\
\text { Bekerja }\end{array}$ & $12.50 \%$ & $0.00 \%$ & $\begin{array}{l}37.50 \\
\%\end{array}$ & $37.50 \%$ & $12.50 \%$ \\
\hline $\begin{array}{l}\text { Bekerja secara } \\
\text { kumpulan / team }\end{array}$ & & Bekerja & $0.00 \%$ & $0.00 \%$ & $\begin{array}{l}15.80 \\
\%\end{array}$ & $36.80 \%$ & $47.40 \%$ \\
\hline
\end{tabular}




\begin{tabular}{|c|c|c|c|c|c|c|c|}
\hline \multirow[t]{2}{*}{ work } & \multirow[t]{2}{*}{$3.5-4.00$} & $\begin{array}{l}\text { Melanjut } \\
\text { kan } \\
\text { Pengajia } \\
\mathrm{n}\end{array}$ & $0.00 \%$ & $0.00 \%$ & $0.00 \%$ & $50.00 \%$ & $50.00 \%$ \\
\hline & & $\begin{array}{l}\text { Belum } \\
\text { Bekerja }\end{array}$ & $0.00 \%$ & $12.50 \%$ & $\begin{array}{l}12.50 \\
\%\end{array}$ & $50.00 \%$ & $25.00 \%$ \\
\hline \multirow{3}{*}{$\begin{array}{l}\text { Penerapan dan } \\
\text { pengalaman } \\
\text { nilai-nilai positif }\end{array}$} & \multirow{3}{*}{$3.5-4.00$} & Bekerja & $0.00 \%$ & $0.00 \%$ & $5.30 \%$ & $52.60 \%$ & $42.10 \%$ \\
\hline & & $\begin{array}{l}\text { Melanjut } \\
\text { kan } \\
\text { Pengajia } \\
\mathrm{n}\end{array}$ & $0.00 \%$ & $0.00 \%$ & $0.00 \%$ & $50.00 \%$ & $50.00 \%$ \\
\hline & & $\begin{array}{l}\text { Belum } \\
\text { Bekerja }\end{array}$ & $12.50 \%$ & $0.00 \%$ & $0.00 \%$ & $50.00 \%$ & $37.50 \%$ \\
\hline
\end{tabular}


